Vol 04 No 2 (2020)
$\begin{gathered}\text { Inventa: Jurnal Pendidikan Guru Sekolah Dasar } \\ \text { http://jurnal.unipasby.ac.id/index.php/jurnal_inventa }\end{gathered}$

\title{
Peningkatan Hasil Belajar Materi Perkalian Dua Buah Bilangan Melalui Strategi Pembelajaran Aritmatika Jari Pada Siswa Kelas II SDN Buncitan Sedati Sidoarjo
}

\author{
Ngunisari Saptowati Handayani \\ Guru SDN Buncitan Sidoarjo
}

Corresponding author email: sarisumianto@gmail.com

\begin{tabular}{ll}
\hline & \multicolumn{1}{c}{ Abstrak } \\
\hline Kata Kunci: & Penelitian ini dilatarbelakangi oleh siswa yang cenderung pasif dalam belajar. \\
Aritmatika, & Siswa memahami perkalian materi yang sulit dari dua bilangan pada \\
dua buah bilangan & pelajaran matematika. Matematika adalah salah satu mata pelajaran yang \\
& kurang disukai anak-anak. Pertanyaan yang menjadi fokus dalam penelitian \\
& ini adalah "Bagaimana cara meningkatkan hasil belajar materi perkalian dua \\
& bilangan matematika siswa kelas II SDN Buncitan Sidoarjo? Tujuannya \\
& adalah untuk mengetahui peningkatan materi pembelajaran hasil belajar \\
& perkalian dua angka mata pelajaran matematika melalui strategi aritmatika \\
& jari kelas II siswa SDN Buncitan Sidoarjo. Jari aritmatika adalah salah satu \\
& strategi pembelajaran matematika yang menggunakan jari sebagai alat untuk \\
& meningkatkan pemahaman materi perkalian dua angka. Untuk memudahkan \\
& bahan ajar dalam perkalian dua angka. strategi pembelajaran mengajar dalam \\
& perkalian dua angka. Penelitian ini menggunakan pendekatan kuantitatif. \\
& Data yang dibutuhkan dalam penelitian ini adalah tes dan observasi. Hasil \\
& yang diperoleh pada strategi pembelajaran aritmatika jari mata pelajaran \\
matematika dasar dapat meningkatkan hasil belajar siswa, terutama dalam & perkalian dua angka.
\end{tabular}

Keyword: arithmetics, jarimatika, multiplication of two numbers

\section{Abstract}

This research is motivated by the students tend to be passive in learning. Students understand difficult material multiplication of two numbers mathematics courses. Math is one subject that is not favored children. Focus question in this research is "How can improve learning outcomes matter multiplication of two numbers mathematics courses second grade students of SDN Buncitan Sidoarjo? The goal is to know the material improvement of learning outcomes multiplication of two numbers mathematics courses arithmetic finger strategy through second grade students of SDN Buncitan Sidoarjo. Arithmetic finger is one of the subjects of mathematics learning strategy that uses the fingers as a tool to improve understanding of the material multiplication of two numbers. To facilitate the teaching material in the multiplication of two numbers. As treasury for teaching learning strategies in the multiplication of two numbers. This study uses a quantitative approach. The data required in this study is testing and observation. The results obtained on the learning strategy arithmetic finger elementary mathematics courses can improve student learning outcomes, especially in the multiplication of two numbers. 


\section{Pendahuluan}

Matematika merupakan salah satu pelajaran yang tidak disukai anak-anak, padahal Matematika merupakan salah satu pengetahuan dasar terpenting untuk sains dan teknologi yang sangat perlu untuk pembangunan. Metode yang dominan, masih menggunakan ceramah sebagai metode pembelajaran yang utama. Siswa cenderung bersifat pasif sehingga menyebabkan sulit untuk memahami materi yang diajarkan dalam proses pembelajaran di kelas, selain itu juga dapat mengakibatkan ketidakmampuan untuk menggali potensi yang dimiliki siswa. Terbukti pada siswa bahwa kemampuan perkalian sangat rendah. Jika metode pembelajaran yang selama ini digunakan menghasilkan output tidak sesuai harapan, seperti yang terjadi di kelas II SDN Buncitan Kecamatan Sedati Kabupaten Sidoarjo. Terbukti dari observasi awal ketuntasan siswa pada mata pelajaran Matematika materi perkalian dua bilangan yang hanya 66,51 ternyata kurang dari KKM yang telah ditentukan yaitu 70 , dari 43 siswa hanya 18 siswa $(41,86 \%)$ yang berhasil mendapatkan nilai di atas KKM, sedangkan 25 siswa $(58,14 \%)$ masih berada di bawah KKM.

Sardiman (2006) dalam pengertian luas mengemukakan bahwa belajar dapat diartikan sebagai kegiatan psiko-fisik menuju ke perkembangan pribadi seutuhnya. Kemudian dalam arti sempit, belajar dimaksudkan sebagai usaha penguasaan materi ilmu pengetahuan yang merupakan sebagian kegiatan menuju terbentuknya kepribadian seutuhnya.

$$
\text { Djamarah (2008) menyebutkan }
$$

belajar adalah serangkaian kegiatan jiwa raga untuk memperoleh suatu perubahan tingkah laku sebagai hasil dari pengalaman individu dalam interaksi dengan lingkungannya yang menyangkut kognitif, afektif, dan psikomotor.

Dimyati dan Mudjiono (2009) hasil belajar merupakan hal yang dapat dipandang dari dua sisi yaitu dari sisi siswa dan dari sisi guru. Dari sisi siswa, hasil belajar merupakan tingkat perkembangan mental yang lebih baik bila dibandingkan pada saat sebelum belajar. Tingkat perkembangan mental tersebut terwujud pada jenis-jenis ranah kognitif, afektif, dan psikomotor. Sedangkan dari sisi guru, hasil belajar merupakan saat terselesaikannya bahan pelajaran.

Berdasarkan uraian tersebut dapat disimpulkan bahwa belajar merupakan upaya-upaya yang melibatkan jiwa dan raga secara keseluruhan untuk menumbuhkembangkan kepribadian yang utuh, perubahan perilaku yang baik sebagai wujud dari pengalaman-pengalaman yang diperoleh individu masing-masing serta sebagai upaya untuk penguasaan materi 
keilmuan menuju manusia yang sempurna dengan kemampuan olah fikir, olah sikap dan olah raga.

Ama (2010) mengemukakan bahwa jarimatika merupakan singkatan jari dan aritmatika. Jarimatika adalah metode berhitung dengan menggunakan jari tangan. Bila kecenderungan pasif siswa ini dirubah melalui strategi pembelajaran aritmatika jari, maka akan terjadi kecenderungan perubahan perilaku belajar siswa dari pasif menjadi aktif yaitu akan selalu mempersiapkan dirinya dan lebih optimal peran sertanya pada setiap proses pembelajaran dengan belajar secara mandiri.

Septi Peni Wulandari (2008) mengemukakan bahwa jarimatika adalah metode berhitung dengan menggunakan jari tangan. Salah satu alternatif bahwa Aritmatika Jari adalah cara berhitung (operasi kali bagi tambah kurang) dengan menggunakan jari-jari tangan. Aritmatika Jari adalah sebuah cara sederhana dan menyenangkan mengajarkan berhitung dasar kepada anak-anak.

Namun demikian menurut Trivia Astuti (2013) mengemukakan bahwa jarimatika adalah suatu cara menghitung matematika yang mudah dan menyenangkan dengan menggunakan jari kita sendiri. Dibandingkan dengan metode lain, jarimatika lebih menekankan pada penguasaan konsep terlebih dahulu kemudian cara cepatnya, sehingga anakanak menguasai ilmu secara matang. Selain itu metode ini disampaikan secara menyenangkan sehingga anak-anak akan merasa senang dan mudah menerimanya. Seperti halnya dalam operasi penjumlahan dan pengurangan, dalam operasi perkalian ini dapat dilakukan perhitungan dengan mudah dan cepat hanya dengan menggunakan 10 jari saja. Metode berhitung dengan jari disebut jarimatika.

\section{Langkah-Langkah penggunaan}

metode Jarimatika kalau dalam operasi penjumlahan dan pengurangan, penyebutan bilangan dengan jari dimulai jari telunjuk kanan sebagai bilangan awal (satuan) dan jari kiri sebagai puluhan, maka dalam perkalian dan pembagian ini, penyebutan bilangan dimulai dari jari kelingking sebagai bilangan terkecil dan ibu jari sebagai bilangan terbesar.

$$
\text { Perbedaan antara operasi }
$$
penjumlahan dan pengurangan dengan operasi perkalian dan pembagian. Bilanganbilangan pada operasi perkalian dan pembagian ini dibagi dalam kelas-kelas atau kelompok-kelompok besar, misalnya 6-10, 11-15, dan seterusnya. Sedangkan, penyebutan bilangan pada masing-masing jari tidak selalu sama, jari kelingking mempunyai nilai 6 , jari manis memiliki nilai 7 , dan seterusnya. 
Demikian pula dengan metode perhitungan dan rumus penerapan tergantung pada kelas dimana operasi itu berlangsung.

Berdasar pada paparan di atas, penulis ingin menjawab permasalahan, Apakah ada peningkatan hasil belajar materi perkalian dua bilangan melalui strategi pembelajaran Aritmatika Jari mata pelajaran matematika siswa kelas II SDN Buncitan Sedati Sidoarjo. Hasilnya diharapkan dapat bermanfaat bagi siswa, untuk meningkatkan pemahaman materi perkalian dua bilangan pada mata pelajaran matematika pada siswa kelas II Sekolah Dasar. Bagi pendidik atau guru, untuk memudahkan di dalam mengajarkan materi perkalian dua bilangan pada siswa kelas II Sekolah Dasar.

\section{Metode}

Penelitian ini merupakan penelitian tindakan kelas (Classroom Action Research). Merupakan kajian sistemik dari upaya perbaikan praktek pendidikan oleh sekelompok guru dengan melakukan tindakan-tindakan dalam pembelajaran, berdasarkan refleksi sekelompok guru mengenai hasil dari tindakan-tindakan tersebut.

Penelitian tindakan kelas berfokus pada penyempurnaan atau peningkatan proses dan praktis pembelajaran dengan tujuan memperbaiki mutu pembelajaran di kelas dengan berfokus pada kelas atau pada proses pembelajaran yang terjadi di kelas dengan ciri khusus adanya tindakan yang nyata.

Desain penelitian yang digunakan adalah penelitian tindakan kelas (PTK) berupa refleksi awal dan observasi untuk mengidentifikasi permasalahan yang terjadi di kelas, dilanjutkan dengan pelaksanaan PTK. Sesuai dengan jenis penelitian, yaitu penelitian tindakan kelas maka dalam desain penelitian ini memiliki tahapantahapan dalam pelaksanaannya. Seperti yang dikemukakan oleh Arikunto (2008:16) secara garis besar terdapat empat tahapan dalam pelaksanaan penelitian tindakan kelas, yaitu (1) perencanaan (planning), (2) pelaksanaan (acting), (3) pengamatan (observing), (4) refleksi (reflecting).

Teknik pengumpulan data merupakan cara pengumpulan data-data yang dibutuhkan untuk membahas hasil penelitian. Data-data yang diperlukan dalam penelitian ini diperoleh melalui observasi pengolahan pembelajaran dengan strategi pembelajaran aritmatika jari yang diakhiri dengan tes formatif buatan guru pada akhir pembelajaran.

Lembar observasi digunakan untuk mengetahui sejauh mana guru dalam melakukan proses pembelajaran telah sesuai dengan desain pembelajaran yang sudah direncanakan sebelumnya. Selain itu lembar observasi juga digunakan untuk mengetahui 
aktivitas guru dan siswa dalam proses pembelajaran. Contohnya apa yang dilakukan guru dalam memulai pembelajaran. Tes formatif dilakukan di akhir pertemuan. Tes formatif buatan guru ini berfungsi untuk (1) untuk menentukan seberapa baik siswa telah menguasai bahan pelajaran yang diberikan dalam waktu tertentu, (2) untuk menentukan apakah suatu tujuan telah tercapai, dan (3) untuk memperoleh suatu nilai.

Penelitian Tindakan Kelas ini akan dianalisis untuk melihat kemampuan siswa dalam mengerjakan soal-soal perkalian dua bilangan yang dinyatakan dengan nilai (score) yang dicapai siswa dari hasil tes.

Untuk mengukur ketuntasan secara klasikal digunakan rumus-rumus menghitung persentase hasil tes adalah :

Rumus

$$
P=\frac{\sum \text { Siswa.yang.tuntas.belajar }}{\sum \text { Siswa }} \times 100 \%
$$

(Zainal Aqib, Dkk, 2009)

Hasil belajar dikatakan meningkat apabila siswa secara individual telah memperoleh nilai KKM 70 atau lebih, dan secara klasikal dikatakan tuntas belajar jika $85 \%$ dari jumlah siswa mendapat nilai 70 atau lebih. Nilai tersebut diperoleh melalui strategi pembelajaran Aritmatika Jari.

\section{Hasil dan Pembahasan}

Hasil penelitian ini dilaksanakan dalam dua siklus, pada masing-masing siklus dikemukakan hasil penelitian mengenai pelaksanaan strategi pembelajaran inovatif, dalam proses pembelajaran untuk pokok bahasan operasional perkalian dua bilangan.

Tabel hasil tes formatif sebelum perbaikan tersebut menunjukkan bahwa nilai terendah 50 dan nilai tertinggi 100 . Nilai ketuntasan belajar adalah 70 , jumlah siswa yang mendapat nilai di bawah 70 ada 25 orang, yang berarti 58,13\% dari jumlah 43 siswa memiliki nilai di bawah taraf penguasaan konsep yang diberikan.

Hasil tes siklus I menunjukkan bahwa nilai rata-rata siswa adalah 72,79 Dengan nilai terendah 50 dan nilai tertinggi 100. Nilai ketuntasan belajar adalah 70 , jumlah siswa yang mendapat nilai diatas 70 ada 28 , yang berarti $65,11 \%$ dari jumlah 43 siswa memiliki nilai di atas taraf penguasaan konsep yang diberikan.

Hasil tes siklus II mengalami peningkatan bahwa siswa yang mencapai ketuntasan belajar sebanyak 43 siswa atau mencapai $100 \%$. Hal itu menggambarkan adanya peningkatan yang sangat signifikan (dari $65,11 \%$ pada siklus I menjadi $100 \%$ pada siklus II). Nilai tertinggi tetap 100, nilai terendah meningkat dari 50 menjadi 70, dan rata-ratanya meningkat pula dari 72,79 menjadi 86,04. Hasil ini menunjukkan bahwa pada perbaikan siklus II mampu meningkatkan hasil belajar siswa 
sehingga kriteria ketuntasan belajar yang ditetapkan (nilai $\geq 70)$ tercapai.

Dari hasil analisis data di atas, maka dapat dibuat pembahasan bahwa kemajuan belajar siswa dalam implementasi strategi pembelajaran aritmatika jari berdasarkan hasil penelitian dengan impelementasi strategi pembelajaran aritmatika jari kemajuan belajar siswa terlihat meningkat dalam pemahaman materi dan kenginan siswa untuk mengetahui materi lebih lanjut.

Siklus I dan siklus II hasil perbaikan menunjukkan bahwa kemampuan siswa dalam pemahaman hitung bilangan bulat dengan menggunakan pembelajaran inovatif. Secara keseluruhan hasil perbaikan menunjukkan peningkatan yang maksimal dengan bukti bahwa pada siklus I nilai ratarata siswa 72,79 dengan persentase ketuntasan belajar $65,11 \%$. Siklus II nilai rata-rata siswa 86,04 dengan persentase ketuntasan belajar $100 \%$.

Hal tersebut disebabkan oleh makin dikuasainya komponen-komponen kemampuan penggunaan jari-jari tangan yang merupakan suatu penyelesaian dalam memahami hitung bilangan bulat dengan pembelajaran inovatif.

Dapat disimpulkan bahwa selama dua kali siklus daya serap kelas II mengalami peningkatan dan jumlah siswa yang berhasil memenuhi KKM/ketuntasan belajar juga meningkat, sehingga diperoleh prosentase ketuntaan belajar kelas II SDN Buncitan Sedati Sidoarjo sebesar 100\%.

\section{Kesimpulan}

Berdasarkan hasil analisis data dapat disimpulkan bahwa melalui strategi pembelajaran aritmatika jari mata pelajaran matematika ada peningkatan hasil belajar materi perkalian dua bilangan pada siswa kelas II SDN Buncitan Sedati Sidoarjo. Melalui implementasi strategi aritmatika jari ini hasil belajar siswa telah mencapai Kriteria Ketuntasan Minimal (KKM) yaitu 70.

Peningkatan hasil belajar tersebut terbukti sebelum perbaikan, dari 43 orang siswa, yang tuntas (memenuhi KKM) 18 orang $(41,86 \%)$, tidaktuntas 25 orang $(58,14 \%)$, dan nilai rata rata siswa 66,51 . Siklus 1, ada 28 siswa tuntas $(65,11 \%), 15$ siswa tidak tuntas $(34,89 \%)$, dan nilai rata rata siswa 72,79. Siklus II, 43 siswa tuntas $(100 \%)$, 0 siswa (0\%) tidak tuntas, dan nilai rata rata siswa 86,04 .

\section{Saran}

Saran-saran yang dapat disampaikan dalam penelitian ini adalah sebagai berikut:

Pembelajaran inovatif sangat tepat diterapkan untuk materi pembahasan yang lain untuk meningkatkan kualitas belajar siswa. Penelitian lebih lanjut tentang strategi ini dapat dilakukan untuk kelas- 
kelas lain dengan soal yang berbeda.

Untuk menilai hasil tes pada pokok bahasan perkalian dua bilangan diperlukan ramburambu penilaian yang jelas agar hasil proses penyelesaian dapat terukur dengan baik. Penelitian ini baru bersifat rintisan dengan segala keterbatasannya. Oleh karena itu, kepada peneliti selanjutnya disarankan agar fokus dan hasil penelitian ini ditindak lajuti dan dikembangkan pula ke arah penelitian yang lebih professional sebagai seorang guru.

\section{Dafatar Rujukan}

A.M, Sardiman. 2006. Interaksi dan Motivasi Belajar-Mengajar. Jakarta. PT Raja Grafindo Persada.

Anitah W, Sri, dkk. 2010. Strategi Pembelajaran di SD. Jakarta: Universitas Terbuka.

Arikunto,2008. PenelitianTindakan Kelas. Jakarta. BumiAksara.

Arsyad, 2007. Media Pembelajaran, Jakarta. Rajawali Pers.

Aqib, Zainal. 2009. PenelitianTindakanKelas. Bandung. AY Rama Media.
Dimyati dan Mudjiono. 2009. Belajar dan Pembelajaran. Jakarta. PT. Rineka Cipta.

Djamarah, Syaiful Bahri. 2008. Psikologi Belajar. Jakarta. Rineka Cipta.

Gulo, W. 2004. Strategi Belajar Mengajar. Jakarta. Grasindo.

Mutaqim, Burhan dan Astuty. Ary .2008. Ayo Belajar Matematika. Pusat Perbukuan Departemen Pendidikan Nasional.

Nopianti, Pipit. 2010. Math Solution Belajar Mudah Matematika. Bandung. Mathematic Solution.

Prasetyo, Dwi, Sunar. 2009. Memahami Jarimatika Untuk Pemula. Diva Press.

Sukirma, dkk. 2009. Matematika. Jakarta. Universitas terbuka.

Trivia, Astuti. 2013. Metode Berhitung Lebih Cepat Jarimatika. Jakarta. Lingkar Media.

Wulandari, Septi Peni. 2008. Jarimatika Perkalian dan Pembagian. Jakarta: PT Kawan Pustaka. 